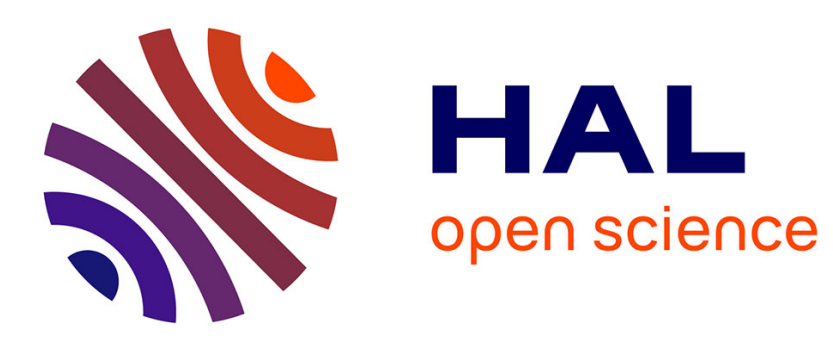

\title{
Potential Lives Saved by Replacing Coal with Solar Photovoltaic Electricity Production in the U.S.
}

\author{
Joshua Pearce, Emily Prehoda
}

\section{To cite this version:}

Joshua Pearce, Emily Prehoda. Potential Lives Saved by Replacing Coal with Solar Photovoltaic Electricity Production in the U.S.. Renewable and Sustainable Energy Reviews, 2017, 80, pp.710-715. 10.1016/j.rser.2017.05.119 . hal-02113454

\section{HAL Id: hal-02113454 https://hal.science/hal-02113454}

Submitted on 28 Apr 2019

HAL is a multi-disciplinary open access archive for the deposit and dissemination of scientific research documents, whether they are published or not. The documents may come from teaching and research institutions in France or abroad, or from public or private research centers.
L'archive ouverte pluridisciplinaire HAL, est destinée au dépôt et à la diffusion de documents scientifiques de niveau recherche, publiés ou non, émanant des établissements d'enseignement et de recherche français ou étrangers, des laboratoires publics ou privés. 
Preprint: Emily W. Prehoda \& Joshua M. Pearce. Potential Lives Saved by Replacing Coal with Solar Photovoltaic Electricity Production in the U.S. Renewable and Sustainable Energy Reviews. doi: http://dx.doi.org/10.1016/j.rser.2017.05.119

\section{Potential Lives Saved by Replacing Coal with Solar Photovoltaic Electricity Production in the U.S.}

\section{Abstract}

Poor air quality from coal combustion adversely impacts human health including mortality and morbidity effects on respiratory, cardiovascular, nervous, urinary, and digestive systems. However, the continued use of coal are no longer necessary to provide for society's electrical needs because of advances in solar photovoltaic (PV) technology. In order to inform health policy this paper reviews the data for quantifying the lives saved by a replacement of U.S. coal-fired electricity with solar PV systems. First the geospatial correlation with coal fired power plants and mortality is determined for the U.S. at the state level. Then, current life cycle mortality rates due to coal combustion are calculated and current energy generation data is collated. Deaths $/ \mathrm{kWh} /$ year of coal and PV are calculated, and the results showed that 51,999 American lives/year could be saved by transitioning from coal to PVpowered electrical generation in the U.S. To accomplish this, 755GW of U.S. PV installations are needed. The first costs for the approach was found to be roughly $\$ 1.45$ trillion. Over the 25 year warranty on the PV modules the first cost per life saved is approximately $\$ 1.1$ million, which is comparable to the value of a human life used in other studies. However, as the solar electricity has value, the cost per life is determined while including the revenue of the solar electric generation using a sensitivity analysis on the value of the electricity. These results found that for most estimations of the value, saving a life by offsetting coal with PV actually saved money as well, in some cases several million dollars per life. It is concluded that it is profitable to save lives in the U.S. with the substitution of coal-fired electricity with solar power and that the conversion is a substantial health and environmental benefit.

Keywords: public health; pollution; photovoltaic; lives; coal; solar energy

\section{Introduction}

Coal combustion for electrical generation not only contributes to high levels of carbon dioxide emissions [1-3] with the concomitant climate disruption [3-6], but also to conventional air pollution [5,7]. Coal fired electrical power plants released $23 \%$ of air pollutants [8] and the largest contributors to U.S. carbon dioxide emission is electrical generation (31\%) [9]. While coal use is declining due to natural gas resources and renewable energy growth [10], coal combustion still accounts for roughly 30$40 \%$ of U.S. carbon dioxide pollution, contributing to ever-expanding climate change [3,12]. Air 
pollutants are classified into four groups: gaseous, persistent organic, heavy metals, and particulate matter [11]. The literature shows a positive correlation between mortality and morbidity due to outdoor air pollution [12-15]. Specifically, it is well established in the historical and current literature that coal combustion results in emissions of carbon dioxide, methane (gaseous pollutants), particulate matter, nitrogen and sulfur oxides (gaseous), and mercury (heavy metal) [2,4,7,12,16-19]. A review of poor air quality from coal combustion is shown in Table 1 . Poor air quality from coal is well known to adversely affect human health including: mortality and morbidity effects on respiratory, cardiovascular, nervous, urinary, and digestive systems. This paper will focus on a review of the mortality due to emissions from coal-fired electrical generation.

Table 1. Major health effects from coal combustion emissions.

\begin{tabular}{|c|c|c|c|}
\hline & Medical Condition & \begin{tabular}{|l|} 
Estimated Affected \\
Individuals*
\end{tabular} & $\begin{array}{l}\text { Coal Emissions } \\
\text { Responsible }\end{array}$ \\
\hline \multirow{3}{*}{ Respiratory } & Asthma & 22.9 million & NOx, PMx* \\
\hline & $\begin{array}{l}\text { Chronic Obstructive } \\
\text { Pulmonary } \\
\text { Disease }\end{array}$ & 12.1 million & NOx, PMx \\
\hline & Lung Cancer & $159,217 *$ & $\mathrm{PMx}$ \\
\hline \multirow{2}{*}{ Cardiovascular } & Heart Attack & 7.9 million & $\mathrm{PMx}$ \\
\hline & $\begin{array}{l}\text { Congestive Heart } \\
\text { Failure }\end{array}$ & 5.7 million & $\mathrm{PMx}$ \\
\hline \multirow{3}{*}{ Neurological } & Ischemic Stroke & 104,000 & $\mathrm{NOx}, \mathrm{PMx}, \mathrm{SO}_{2}$ \\
\hline & $\begin{array}{l}\begin{array}{l}\text { Developmental } \\
\text { delays }\end{array} \\
\end{array}$ & 637,233 & Mercury $^{70}$ \\
\hline & & & \\
\hline
\end{tabular}

*Estimated affected individuals include both mortality and morbidity rates. PMx (particulate matter) encompasses particulate matter size between 2.5 and 10 micrometers. NOx (nitrogen oxide) [3,11$13,20]$.

A full life cycle accounting of coal reveals an estimated $\$ 523.3$ billion in damages (including social and environmental externalities), which is roughly $\$ 0.27 / \mathrm{kWh}$ generated [7]. Thus, the externalities of coal-fired electricity are more than double the average cost of residential electricity in the U.S. of $\$ 0.12 / \mathrm{kWh}$ [21]. Although coal is detrimental in all stages of its life cycle, combustion is the stage with the heaviest health burden [16] in the form of mortality and morbidity effects due to outdoor air pollutants/emissions (see Table 1).

Most research devoted to addressing issues of coal degraded air quality has focused on mitigation of coal plant emissions using regulations and mechanisms such as cap and trade through permits [22], which are vigorously opposed by the coal industry [23]. These mechanisms decreased some gaseous pollutants by targeting sulfur and nitrogen oxides through a cap and trade regulatory 
policy [24]. Particulate matter (absorbed through inhalation and ingestion) and carbon dioxide (impacts climate processes) continue to pose severe risks $[17,25]$. Particulate matter is directly linked to increased mortality due to lung cancer and respiratory disease [12,26].

Fortunately, the continued use of coal and the required complicated emissions controls are no longer necessary to provide for society's electrical needs because of advances in renewable energy sources such as solar photovoltaic (PV) technology $[1,4,27]$. PV produces no emissions or generate liquid or solid wastes during use and has a well-established environmentally-friendly ecological balance sheet [28-33]. The environmental benefits of PV are found in net energy studies [28], life cycle analysis studies [29,32], emission studies from PV [30], sustainability indicators [31] and when compared to other energy sources [33]. Integrating rooftop solar has potential to provide $39 \%$ of the total U.S. electrical generation [34] and with the potential to build solar farms on unused tracks of land [35], transitioning to solar PV has potential to replace coal as an energy source entirely [36-37]. Thus, by replacing coal-fired electricity with PV-generated electricity there is an expected decrease in air and waste emissions (e.g. greenhouse gases and air pollution particulates) that affect overall air quality and would be expected to improve human health. However, how significant this health impact would be is not known.

In order to inform health policy the objective of this review is to evaluate past research to quantify the American lives saved by a complete elimination of the domestic coal industry with the scale up of solar PV systems. First the geospatial correlation with coal fired power plants and mortality is determined for the U.S. at the state level. Then, current life cycle mortality and morbidity rates due to coal combustion are reviewed and current energy generation data is used to determine the current lives saved by PV and the increase in U.S. PV installations to replace coal-fired electrical generation entirely. Then, American deaths/kWh of coal and PV per year are calculated, enabling health policy analysts to determine the number of lives currently saved by existing PV production and the potential for eliminating all premature deaths from coal combustion in the U.S. The first costs for the approach is calculated per lives saved over the life time of the PV systems. Finally, the cost per life is determined while including the revenue of the solar electric generation using a sensitivity analysis on the value of the electricity. Public health impact results and policy interventions are discussed.

\section{Methods}

Coal-fired electricity emissions [38] were geolocated in the U.S to illustrate the geospatial relationship between coal emissions related mortality. Two shapefiles were obtained from the ArcGis database to analyze current air pollution due to coal-fired electrical production in the United States: (1) a shapefile of the U.S. [39], and (2) a shapefile of the current U.S. coal electrical plants [40]. This data was then transcribed on a map utilizing ArcMap 10.3.1 to indicate potential areas for PV penetration. Then annual mortality due to coal emissions per 100,000 people was added to the map [41].

Total U.S. electrical generation was obtained to quantify the percentage of kWh produced by coal and solar PV in the U.S. [42]. Current U.S. solar penetration data was obtained to provide for the baseline of PV lives saved now and in order to calculate the amount of PV needed to replace coal-fired electrical generation entirely. Current solar PV penetration has reached roughly 27.4 GW [43]. This aggregate of solar PV produces $2.32 \times 10^{7} \mathrm{kWhrs} /$ year [44].

In order for PV to completely eliminate coal, the total DC rated power of PV needed, $\mathrm{S}_{\mathrm{T}}$, is calculated as follows:

$$
S_{T}=\frac{C_{T}}{(I \times 365)} * 10^{-6}[\mathrm{GW}]
$$


where $\mathrm{C}_{\mathrm{T}}$ is the total amount of coal-fired electricity produced per year (1.32 $\left.\mathrm{x} 10^{12} \mathrm{kWh} / \mathrm{year}\right)$ [45], and I, which is measured in $\mathrm{kWh} / \mathrm{m}^{2} /$ day, is the population weighted average U.S. peak sun hours per day that represents solar flux for solar PV generation and is determined by:

$$
I=\sum_{s=1}^{50} \frac{\left(P_{s} I_{s}\right)}{P_{T}}\left[\mathrm{kWh} / \mathrm{m}^{2} / \mathrm{day}\right]
$$

Where $P_{s}$ is the 2015 population of each state [46], $I_{s}$ is the average solar flux in each state [47], and $\mathrm{P}_{\mathrm{T}}$ is the total 2015 U.S. population [40]. It was found to be $4.79 \mathrm{kWh} / \mathrm{m}^{2} /$ day.

There is a rich history of mortality studies on energy sources. The contribution to mortality was quantified utilizing a review of the secondary sources for coal [13,14,48-50] and PV [29,32,51,52]. A quantification of emissions throughout the entire life cycle of coal was necessary to determine the average U.S. number of premature deaths per year, $\mathrm{F}_{\mathrm{c}}$. The coal-fired electricity life cycle is divided into four components: extraction, transport, processing, and combustion [7]. The solar-photovoltaic system life cycle is divided into 5 components: mining, purification, manufacturing, operation, and recycling [30]. Waste, in the form of emissions, is calculated at each stage of the technologies life cycle and is aggregated.

Thus, the electricity generation death rate for coal, $\mathrm{r}_{\mathrm{c}}$ is given by:

$$
r_{C}=\frac{D_{T C}}{C_{T}} \quad \text { [American deaths } / \mathrm{kWh} / \text { year }
$$

where $\mathrm{D}_{\mathrm{TC}}$ is the total number of deaths due to coal fired electrical emissions, which is 52,000/year [53].

The electricity generation death rate for solar photovoltaic technology, $\mathrm{r}_{\mathrm{PV}}$, is given by:

$$
\left.r_{P V}=\frac{D_{T P V}}{E_{T P V}} \quad \text { [U.S. deaths } / \mathrm{kWh} / \text { year }\right]
$$

where the total energy generated by $\mathrm{PV}, \mathrm{E}_{\mathrm{TPV}}$ is $2.32 \times 10^{7} \mathrm{kWh} /$ year [44] or $2.65 \times 10^{-3} \mathrm{GW}$ yr/year, where the GW-yr is a unit of energy. The total deaths per year due to PV is more challenging to determine. For thin film amorphous silicon PV the value is currently zero based on the limited number of cases in the U.S. Environmental Protection Agencies Risk Management Program database [29]. The actual values of deaths from other PV materials is similarly not available. To remain conservative, the values for crystalline silicon-based PV (both mono- and multi-crystalline silicon) with crystal silicon (c-Si)-based semiconductor industry. This assumption is reasonable because both the semiconductor industry and the PV industry are dominated by the processing of silicon materials [54]. c-Si-base solar cells can be fabricated via a chemical route (quartz, carbothermic reaction, chemical purification and then wafer and cell production) or a metallurgical route (quartz, carbothermic reduction, metallurgical purification and then wafer and cell production). Up to the wafer stage the processing is identical for both industries with the semiconductor industry refining the silicon only to a higher purity for wafers. In addition, many of the processes for cleaning are used by both industries as well (e.g. the use of four step RCA clean using water, ammonium hydroxide , and hydrogen peroxide (5:1:1); aqueous hydrofluoric acid (1:50 or 1:100); water, hydrochloric acid and hydrogen peroxide (6:1:1); and 
160

161

162

163

164

165

166

167

168

169

170

171

172

173

174

175

176

177

178

179

180

181

182

183

184

185

186

187

188

189

190

191

192

193

194

195

196

deionized water). For device fabrication the doping processes are also the same (e.g. p doping boron with and $\mathrm{n}$ doping with phosphorus). The steps to form a transistor in the semiconductor are different from a p-n junction PV device, however, they result in the deposition of relatively small amounts of other materials (e.g. gate oxides and contacts). Thus, the deaths for c-Si-based PV will be estimated from the values of material used weighted number of deaths from chemical accidents in the larger chemical industry involving listed hazardous substances that are also used in solar cell or PV module manufacturing (e.g. $\mathrm{SiHCl}_{3}$ and $\mathrm{SiH}_{4}$ for silicon processing $\mathrm{AsH}_{3}, \mathrm{PH}_{3}$, and $\mathrm{B}_{2} \mathrm{H}_{6}$ for doping , and $\mathrm{HF}$ and $\mathrm{Hcl}$ for cleaning). This provides less than $10^{-4}$ deaths per GWyr, which is far safer than coal $[29,32]$. The $\mathrm{D}_{\mathrm{TPV}}$, deaths per year from PV, is currently amounts to $2.648 \times 10^{-7}$ deaths/year (e.g. far less than 1).

The total lives (L) saved per kWh of solar PV electricity production offsetting coal-fired electrical generation is given by:

$$
\left.L=r_{c}-r_{P V} \quad \text { [U.S. lives saved } / \mathrm{kWh}\right]
$$

Utilizing current industrial PV costs, $\mathrm{P}$, of $\$ 1.92 / \mathrm{W}$ [55], the first cost per life, $\mathrm{C}_{\mathrm{FL}}$, saved by purchasing a PV system to offset coal use nationally is calculated as follows:

$$
C_{F L}=\frac{\left[\left(S_{T} \times 10^{9} \frac{W}{G W} \times P\right)\right]}{\left(l_{p v} \times F_{c}\right)} \text { [First cost \$ invested/U.S. lives saved in PV lifetime] }
$$

Where $\mathrm{S}_{\mathrm{T}} \mathrm{x} 10^{9}$ is total solar in $\mathrm{GW}$ converted to $\mathrm{W}$, and $\mathrm{F}_{\mathrm{c}}$ represents the number of fatalities due to coal combustion emissions per year and $\mathrm{l}_{\mathrm{pv}}$ is the lifetime of the PV. However, unlike conventional health policy interventions that only have a first cost, this policy would also generate revenue, which must be taken into account, which allows for a cost per life, $\mathrm{C}_{\mathrm{L}}$, over a specific period, $\mathrm{T}$ :

$$
C_{L}(T)=\frac{\left[\left(S_{T} \times 10^{9} \frac{W}{G W} \times P\right)-\left(C_{T} \times T \times v\right)\right]}{\left(T \times F_{c}\right)}[\$ / \text { U.S. lives saved over T years] }
$$

Where $v$ is the $\$ / \mathrm{kW}$-hrs of the PV generated electricity replacing all of coal. A sensitivity analysis is run on $v$ and to avoid complications the energy cost escalation rate is assumed to track with inflation.

\section{Results}

There is a clear correlation between annual mortality due to coal emissions and the geographic locations of coal fired power plants in the U.S. as can be seen in Figure 1. Dense regions of mortality are correlated with high coal-fired electrical emissions in the central and northeast of the U.S. Emissions from coal-fired electricity total $1.57 \times 10^{9}$ million metric tons in 2013 [9]. 
198 Using equations 1 and 2, to completely replace coal-fired electricity would require 755 GW of solar $1.14 \times 10^{-14}$ deaths/kW-hr from equation 4 . It is clear that from a human mortality standpoint PV is far safer than coal produced electricity. This is quantified in equation 5, which provides $3.9393927 \times 10^{-8}$ lives saved per $\mathrm{kW}$-hr as the respective death rates are 6 orders of magnitude larger for coal than PV. If the entire U.S. coal fired electricity production were switched to PV production. This would result in 51,999 American lives saved per year.

Installing 755GW of PV in the U.S. at \$1.92/W [56], would cost the U.S roughly $\$ 1.45$ trillion dollars. Following equation 6 and using a 25 year warranty on the PV modules as the lifetime this results in a first cost per American life saved of roughly \$1.1 million per life. However, there are several complicating factors, first the output efficiency of PV modules degrades with time. For most technical studies this has been shown to be $0.5 \%$ per year degradation rate or less and that is what is used in PV economic studies [57]. The warranty for PV and its effective lifetime is set at 25 years, although it is clear the real lifetime of the PV would be much greater than that. In general the 25 year warranty for PV guarantees the PV power is performing at $80 \%$ of the initial rated power or better. Thus, to remain conservative these factors both decrease and increase cost per life respectively, they have been assumed to roughly cancel out and be ignored. The far more important complicating factor of using PV replacement of coal as a public health policy measure is the value of PV-generated electricity. Using 25 years again and equation 7 the cost per life varies substantially depending on the value assigned to the electricity as seen in Table 2, which ranges from over \$1.1 million per life saved if the electricity has no value, through coal generation with zero value placed on externalities [57], and net metering through various scenarios [58], the calculated value for solar [59] to $-\$ 4.6 \mathrm{~m}$ per life saved if the residential retail rate is used in an isolated rural community [60].

Table 2. The Value of solar PV-generated electricity and the impact on the cost per life saved.

\begin{tabular}{|l|l|l|l|}
\hline $\begin{array}{l}\text { Method of Valuing Solar Elec- } \\
\text { tricity }\end{array}$ & US\$/kWhr & $\begin{array}{l}\text { Solar PV US\$ } \\
\text { value/year }\end{array}$ & $\begin{array}{l}\text { Cost per Life } \\
\text { (US\$/life) }\end{array}$ \\
\hline No value & 0 & 0 & $\$ 1,115,076$ \\
\hline Coal generation only [57] & $\$ 0.0323$ & $\$ 4.26 \times 10^{10}$ & $\$ 295,153$ \\
\hline Net metering industrial [58] & $\$ 0.068$ & $\$ 8.98 \times 10^{10}$ & $\mathbf{- \$ 6 1 1 , 0 7 7}$ \\
\hline Net metering commercial [58] & $\$ 0.1050$ & $\$ 1.39 \times 10^{11}$ & $\mathbf{- \$ 1 , 5 5 0 , 3 0 8}$ \\
\hline Net metering residential [58] & $\$ 0.1261$ & $\$ 1.66 \times 10^{11}$ & $\mathbf{- \$ 2 , 0 8 5 , 9 2 3}$ \\
\hline Value of Solar Minnesota [59] & $\$ 0.145$ & $\$ 1.91 \times 10^{11}$ & $\mathbf{- \$ 2 , 5 6 5 , 6 9 3}$ \\
\hline Net metering Houghton, MI [60] & $\$ 0.2273$ & $\$ 3.00 \times 10^{11}$ & $\mathbf{- \$ 4 , 6 5 4 , 8 4 7}$ \\
\hline
\end{tabular}

\section{Discussion}

Although, Figure 1 illustrates areas of high emissions due to coal-production, it is important to note that air pollution can be dispersed through the air and affect regions at large distances from the source $[5,15]$. Carbon dioxide indirectly results in premature death due to climate change events and according to WHO analyses, climate change is expected to cause 250,000 additional deaths per year between 2030 and 2050 [3,64]. Decreases in sulfur dioxides results from burning “clean coal”, washing coal, and utilizing scrubbers to chemically remove sulfur dioxide from coal burning smokestacks, 
resulted in decreasing sulfur dioxide levels from $15.7 \mathrm{~m}$ tons in 1990 to $10.2 \mathrm{~m}$ tons in 2005 [61]. This was completed through cap and trade-based policy. The EPA issued control standards under clean air act, which includes $\mathrm{NO}_{\mathrm{x}}, \mathrm{SO}_{2}$, and $\mathrm{PM}_{\mathrm{x}}$. Decreases in particulate matter may not be correlated with decreased mortality as there is no well-defined safe threshold for particulate matter [12]. Particulate matter made up of smaller particles, which travel deep into respiratory tract and become lodged permanently [62]. Thus, despite improvements coal emissions remain a significant threat to mortality rates in the U.S. This paper found that a large number of premature deaths, about 52,000 in the U.S. due to coal-fired emissions during electrical generation, could be eliminated by a conversion to PVbased electrical generation.

To accomplish this national health benefit the amount solar PV needed to mitigate premature death due to coal-fired electrical production was $755 \mathrm{GW}$. 755GW is a significant increase over current U.S. PV penetration levels (27.4GW). Thus, only 3.6\% of the PV necessary to prevent the current life loss from coal pollution is available. It should also be pointed out that there are some lifecycle emissions from PV [7, 30, 51, 63]. However, the full life cycle of PV produces a fraction of the carbon dioxide equivalent emissions when compared to coal [30, 64, 65]. Air pollution throughout full life cycle of PV tends to vary with materials used during manufacture and mining [63], however, the negative environmental impacts of PV generally involve accidental operation error [66,67]. In summary, the substitution of coal-fired electricity with solar power is a substantial health and environmental benefit and clear path towards a more sustainable state [27].

This study made several estimations to obtain these values, which should be pointed out. First, the population weighted average of solar flux was used to determine the energy generation rather than a detailed analysis of the geographic variation of PV production potential across the U.S. For the purposes of this study the error introduced with this method is small, but more detailed studies on both the rooftop PV potential [68-70] and the solar farm [35] and even agrivoltaic [71,72] potential, would provide a more granular (e.g. including shading losses) estimates for decision makers (e.g. at the state or community level). Second, the premature deaths from coal related emissions are actually conservative. This study provided analyses of only the combustion step in coal electrical generation in the United States. To capture the full scope of mortality rates in the U.S., analyses must be expanded to include the full life cycle of coal; this includes sectors other than electrical (industry, manufacture of synthetic fuel, or manufacturing steel) that utilize coal. Other externalities exist for coal, including land use, water pollution, natural resource depletion, habitat destruction [73]. These uncertainties must be quantified for both coal and solar PV to determine accurate measure of lives saved by replacing one electrical generation source for another. However, it is clear from the results that the potential American lives at stake, which can be saved by a policy intervention is warranted that encourages more rapid deployment of PV.

Performing a similar analysis at a global scale could be of use to policy makers and the United Nations to satisfy Sustainable Development Goal \#7: Ensure access to affordable, reliable, sustainable, and modern energy for all [74], while significantly reducing global lives sacrificed to current coal combustion. Current global outdoor air pollution is concentrated in developing nations due to continued increase of coal use [18]. As a result, larger mortality rates of developing nations are expected to continue $[12,48]$. The World Health Organization estimates 7 million deaths per year due to air pollution (of these 2.6 million are linked to outdoor air pollution), making it the single largest environmental risk today [75]. Air pollution related mortality outweighs global car accidents (1.3 million people [76]) by a factor of five and natural disasters by a factor of 28 (mortality ranging from 20,000-250,000 people depending on the year) [77]. It can thus be assumed that the deaths per unit energy will be even more extreme on the global scale as the U.S. environmental protection standards are more advanced than much of the world. In addition, this does not take into account the potential 
279

280

premature deaths aggravated by climate change for which the Intergovernmental Panel on Climate Change (IPCC) already recommends immediate action to reduce emissions by 2050 [78].

To meet the health-related demand of eliminating coal pollution with solar power in the U.S., $\$ 1.45$ trillion dollars would need to be invested in new PV generation. This is the total cost to save all future lives in the U.S. from coal-related electricity over the next twenty-five years. Even with no value the cost per life is only $\$ 1.1 \mathrm{~m}$, which is on the lower end of the values normally ascribed to human life (between $\$ 1$ and $\$ 9$ million) [79-81]. However, unlike other health policy interventions, which only cost money up front [82], PV replacement of coal production also has the potential to generate significant revenue as shown in the third column of Table 2 . Table 2 provides a sensitivity analysis on the value of the solar electricity, which is currently under intense debate in the electrical industry. PV is inherently distributed so using the centralized coal value of electricity of $\$ 0.03 / \mathrm{kWhr}$ is misleadingly pessimistic. In most of the U.S. PV is currently net metered making the values between $\$ 0.06-0.12 / \mathrm{kWhr}$ more realistic. As can be seen in Table 2, all of these values actually have a net economic benefit for saving lives from only the value of electricity. There has also been a strong case made [59] that net metering actually represents a subsidy to electric utilities as the value of solar can be higher (e.g. \$0.14/kWhr in Minnesota). When looking at the potential for isolated communities to adopt solar the current high costs of electricity turn the potential economic savings per life save truly substantial. As technology has progressed to such a point that PV, battery and cogen units can displace the use of the grid in even the most extreme circumstances [83-86], these levels of savings are possible for the small populations living in such regions [60]. The use of PV to offset coal-fired electricity compares exceptionally favorably to more conventional forms of health policy interventions, the best of which (e.g. helping children in developing nations [87]) still costs a few thousand per life rather than conserving money.

The results clearly show, premature deaths due to anthropogenic effects (coal combustion and pollution) can be mitigated through anthropogenic efforts (PV electrical energy conversion). Policies can be developed at many scales (international, federal, state, and local levels) to contribute to the concerted climate change mitigation efforts. There are several policy interventions that could accelerate PV adoption: 1) Effective renewable portfolio standards (RPS) programs [88] and Mandatory Green Power Option (MGPO) [89] can be implemented at the state level. As air pollution is not limited to state boundaries, as is shown in Figure 1, requiring states to design RPS programs would decrease emissions from electrical generation. Federal agencies, such as the EPA, can strengthen particle pollution standards, which can indirectly lead the electrical industry to adopt renewable energy generation systems [90, 91]. An alternative strategy includes instituting state taxes or carbon trading mechanisms [92, 93] on coal usage. States and industries that continue coal usage would pay higher taxes to internalize environmental and health effects. EPA regulations such as Mercury and Air Toxics Standards, are responsible for the decommissioning of $72 \mathrm{GW}$ of coal electrical generating capacity [94]; this number is expected to rise by 2020. On the other hand, increasing federal incentives for solar PV will likely result in a rapid transition to cleaner energy generation. It is important to note that a portfolio of these policy implementations will be more effective in reducing emissions and promoting renewables than any single policy or program [90]. In the context of mortality in the U.S., exploring and adapting wartime mobilization strategies [95] to a national solar PV electrical transition may provide enough emission mitigation to slow anthropogenic climate change effects.

Finally, this study has only explored the impact of coal-fired electricity conversion to solar PV on mortality. However, current air pollution costs also occur in medical costs and lost productivity. In 2010, OECD nations spent roughly $\$ 1.7$ trillion in attempts to combat and treat effects from outdoor air pollution [96]. The U.S. spends roughly $\$ 185$ billion per year on coal emission effects; these represent only health related costs [7]. California alone spent \$193 million in hospital care in 2007 due to air 
pollution effects [97]. It has long been established that energy policy creates horrendous public health problems and injustices [98], and this study makes clear large scale PV deployment to eliminate coal could help alleviate this historical problem. Future work can help quantify the values of these other effects from a transition from coal to solar based electrical generation.

\section{Conclusions}

The results of this study showed a clear geospatial correlation between coal fired power plants and mortality from air pollution is the U.S. at the state level. To reduce these deaths coal-fired electricity must be eliminated and the results showed that 51,999 American lives could be saved per year by transitioning from coal to PV-powered electrical generation in the U.S. To accomplish this, 755GW of U.S. PV are needed and the first costs for such an national array are $\$ 1.45$ trillion. Over the 25 year warranty on the PV modules the first cost per life saved is approximately \$1.1 million, which is comparable to the value of a human life used in other studies. However, as the solar electricity has value, the cost per life for offsetting coal with PV actually saved money as well, in some cases several million dollars per life. It is concluded that it is profitable to save lives in the U.S. with the substitution of coal-fired electricity with solar power and that the conversion is a substantial health and environmental benefit. Evolving the U.S. energy system utilizing clean, alternative technology will allow the U.S. to prevent thousands of premature deaths along with becoming a global leader in renewable technology adoption.

\section{References}

[1] Sims, R, Rogner, H, Gregory, K. Carbon emission and mitigation cost comparisons between fossil fuel, nuclear and renewable energy resources for electricity generation. Energy Policy 2003; 31(13): 1315-1326.

[2] Markandya, A, Wilkinson, P. Electricity generation and health. The Lancet 2007; 370(9591): 979-990.

[3] Lockwood, A, Welker-Hood, K, Rauch, M, Gottlieb, B. Coal's assault on human health. Report from Physicians For Social Responsibility 2009; 3-16.

[4] Weisser, D. A guide to life-cycle greenhouse gas (GHG) emissions from electric supply technologies. Energy 2007; 32(9): 1543-1559.

[5] Fenger, J. Air pollution in the last 50 years- from local to global. Atmospheric Environment 2009; 43(1): 13-22.

[6] Gohlke, J, Thomas, R, Woodward, A, Campbell-Lendrum, D, Pruss-Ustun, A, Hales, S, Portier, C. Estimating the Global Public Health Implications of Electricity and Coal Consumption. Environmental Health Perspectives 2011;119(6): 821-826.

[7] Epstein, P, Buonocore, J, Eckerle, K, Hendryx, M, Stout B, Heinberg, R, Clapp, R, May, B, Reinhart, N, Ahern, M, Doshi, S, Glustrom, L. Full cost accounting for the life cycle of coal. Ecological Economics Reviews 2011;1219:73-98.

[8] EPA. US GHG Inventory Report [Internet]; 2014 [cited on 2016 Feb 12] available at: https://www3.epa.gov/climatechange/ghgemissions/usinventoryreport.html

[9] EPA. Sources of Greenhouse Gas Emissions. [Internet]; 2014 [cited 2016 Feb 15] available from: https://www3.epa.gov/climatechange/ghgemissions/sources/electricity.html

[10] Reboredo, J.C., 2015. Renewable energy contribution to the energy supply: Is there convergence across countries?. Renewable and Sustainable Energy Reviews, 45, pp.290-295. 
[11] Kampa, M, Castanas, E. Human health effects of air pollution. Environmental Pollution 2008;151(2): 362-367.

[12] Curtis, L, Rea, W, Smith-Willis, P, Fenyves, E, Pan, Y. Adverse health effects of outdoor air pollutants. Environment International 2006;32(6): 815-830.

[13] Hendryx, M. Mortality from heart, respiratory, and kidney disease in coal mining areas of Appalachia. International Archives of Occupational and Environmental Health 2007;82(2):243-249.

[14] Hendryx, M, Zullig, K. Higher coronary heart disease and heart attack morbidity in Appalachian coal mining regions. Preventive Medicine 2009;49(5):355-359.

[15] Yim, S, Barrett, S. Public Health Impacts of Combustion Emissions in the United Kingdom. Environmental Science and Technology 2012;46(8):4291-4296

[16] Gaffney, J, Marley, N. The impacts of combustion emissions on air quality and climate from coal to biofuels and beyond. Atmospheric Environment 2009;43(1): 23-36.

[17] Smith, K, Frumkin, H, Balakrishnan, K, Butler, C, Chafe, Z, Fairlie, I, Kinney, P, Kjellstrom, T, Mauzerall, D, McKone, T, McMichael, A, Schneider, M. Energy and human health. Annual Review of Public Health 2013;34:159-188.

[18] Finkelman, R, Orem, W, Castranova, V, Tatu, C, Belkin, H, Zheng, B, Lerch, H, Maharaj, S, Bates, A. Health impacts of coal and coal use: possible solutions. International Journal of Coal Geology 2002;50(1-4); 425-443.

[19] Melody, S, Johnston, F. Coal mine fires and human health: what do we know? International Journal of Coal Geology 2015;152(Part B): 1-14.

[20] Clancy, L, Goodman, P, Sinclair, H, Dockery, D. Effects of air-pollution control on death rates in Dublin, Ireland: an intervention study. The Lancet 2002;360(9341):1210-1214.

[21] EIA, Electric Power Monthly. [Internet]; 2016 [cited on 2016 Mar 2]. Available at: https://www.eia.gov/electricity/monthly/epm table grapher.cfm?t=epmt 56 a

[22] Stavins, R. Addressing climate change with a comprehensive U.S. cap and trade system. Oxford Review of Economic Policy 2008;24(2): 298-321.

[23] Stavins, R. What can we learn from grand policy experiment? Lessons from SO2 allowance trading. Journal of Economic Perspectives 1998;12(3):69-88.

[24] EPA. 2013 Progress Reports. [Internet]; 2013 [cited on 2016 Mar 2]. Available at: , https://www3.epa.gov/airmarkets/progress/reports/index.html

[25] O'Neill, B, Liddle, B, Jiang, L, Smith, K, Pachauri, S, Dalton, M, Fuchs, R. Demographic change and carbon dioxide emissions. The Lancet 2012;380(9837):157-164.

[26] Gohlke, J.M., Thomas, R., Woodward, A., Campbell-Lendrum, D., Prüss-Üstün, A., Hales, S. and Portier, C.J. Estimating the global public health implications of electricity and coal consumption. Environmental Health Perspectives 2011;119(6), 821.

[27] Pearce, J. M. Photovoltaics — a path to sustainable futures. Futures 2002;34(7): 663-674.

[28] Pearce, J. and Lau, A., 2002, January. Net energy analysis for sustainable energy production from silicon based solar cells. In ASME Solar 2002: International Solar Energy Conference (pp. 181-186). American Society of Mechanical Engineers.

[29] Fthenakis, V.M., Kim, H.C., Colli, A. and Kirchsteiger, C., 2006. Evaluation of risks in the life cycle of photovoltaics in a comparative context. In 21st European Photovoltaic Solar Energy Conference.

[30] Fthenakis, V, Chul Kim, H, Alsema, E. Emissions from photovoltaic life cycles. Environmental Science and Technology 2008;42(6):2168-2174.

[31] Evans, A, Strezov, V, Evans, T. Assessment of sustainability indicators for renewable energy technologies. Renewable and Sustainable Energy Reviews 2009;13(5):1082-1088. 
[32] Fthenakis, V.M, Kim, H.C. Photovoltaics: Life-cycle analyses. Solar Energy, 2011;85(8):1609-1628.

[33] Solangi, K, Islam, M, Saidur, R, Rahim, N, Fayaz, H. A review on global solar energy policy. Renewable and Sustainable Energy Reviews 2011;15(4):2149-2163.

[34] Gagnon, P, Margolis, R, Melius, J, Phillips, C, \& Elmore, R. Rooftop Solar Photovoltaic Technical Potential in the United States: A Detailed Assessment 2016;(No. NREL/TP-6A2065298). NREL (National Renewable Energy Laboratory (NREL), Golden, CO (United States).

[35] Nguyen, H.T. and Pearce, J.M., 2010. Estimating potential photovoltaic yield with r. sun and the open source geographical resources analysis support system. Solar Energy, 84(5), pp.831-843.

[36] Zweibel, K, Mason, J, Fthenakis, V. A solar grand plan. Scientific American 2008;298(1):64-73.

[37] Duan, H, Zhang, G, Zhu, L, Fan, Y. Wang, S. How will diffusion of PV solar contribute to China's emissions-peaking and climate responses? Renewable and Sustainable Energy Reviews, 2016;53:1076-1085.

[38] EIA, Electrical Power Annual 2010. [Internet]; 2011 [cited on 2016 Mar 12]. Available at: http://www.eia.gov/electricity/annual/archive/03482010.pdf

[39] Fitzpatrick, C. US 50 States + DC shapefile. ArcGis Database. 2012 Feb 1 [cited on 2015 Oct 4]. Available from: https://www.arcgis.com/home/item.html?id=f7f805eb65eb4ab787a0a3e1116ca7e5.

[40] ArcGIS. U.S. Coal Plants, emissions, and attributed health issues. [Internet] 2014 [cited on 3016 Apr 1]. Available at: http://www.arcgis.com/home/item.html? id=e31814ad804549c987f159e9a2f8eaf4

[41] Schneider, C, Banks, J. The toll from coal: an updated assessment of death and disease from America's dirtiest energy source. CATF. 2010.

[42] EIA. Total Energy. [Internet]; 2013 [cited on 2016 Apr 1]. Available at: http://www.eia.gov/totalenergy/data/monthly/pdf/sec7 5.pdf

[43] SEIA. Solar Market Insight. [Internet] 2015 [cited on 2016 Mar 4]. Available at:, http://www.seia.org/research-resources/us-solar-market-insight

[44] EIA. Net Generation from Renewables. [Internet]; 2016 [cited on 2016 Mar 11]. Available at: http://www.eia.gov/electricity/monthly/epm table grapher.cfm?t=epmt $101 \mathrm{a}$ [45] EIA. What is U.S. Electricity Generation by Source. [Internet]; 2015 [cited on $2016 \mathrm{Apr}$ 1]. Available at: https://www.eia.gov/tools/faqs/faq.cfm?id=427\&t=3

[46] U.S. Census. Population Estimates. [Internet]; 2015 [cited on 2016 Apr 15]. Available at: https://www.census.gov/popest/data/counties/totals/2015/index.html

[47] NREL (National Renewable Energy Laboratory). Annual direct normal solar radiation 8 years mean value (1998-2005). SUNY 20km satellite mode 2007.

[48] Cohen, A, Anderson, H, Ostra, B, Pandy, K, Krzyzanowski, M, Kunzli, N, Futschmidt, K, Pope, A, Romieu, I, Samet, J, Smith, K. The global burden of disease due to outdoor air pollution. Journal of Toxicology and Environmental Health 2005;68(13-14): 1-7.

[49] Hendryx, M. Mortality Rates in Appalachian Coal Mining Counties: 24 Years Behind the Nation, Environmental Justice, 2008;1(1):5-11.

[50] Penney, S, Bell, J, Balbus, J. Estimating the health impacts of coal-fired power plants receiving international financing. Report at ENVIRONMENTAL DEFENCE FUND 2009.

[51] Fthenakis, V, Chul-Kim, H. Greenhouse-gas emissions from solar electric- and nuclear power: A life-cycle study. Energy Policy 2007;35(4):2549-2557. 
[52] Hirschberg, S, Dones, R, Heck, T, Burgherr, P, Schenler, W, Bauer, C. Sustainability of electricity supply technologies under German conditions: a comparative evaluation. PSI, 2004. [53] Caiazzo, F, Ashok, A, Waitz, I, Yim, S, Barrett, S. Air pollution and early deaths in the United States. Part I: Quantifying the impact of major sectors in 2005. Atmospheric Environment 2013;79: 198-208.

[54] Miles RW, Zoppi G, Forbes I. Inorganic photovoltaic cells. Materials today. 2007 Nov 30;10(11):20-7.

[55] U.S. DOE SunShot. Photovoltaic system pricing trends. [Internet]; 2014 [cited on 2016 Mar 20]. Available at: http://www.nrel.gov/docs/fy14osti/62558.pdf

[56] Branker, K, Pathak, MJM, Pearce, JM. A review of solar photovoltaic levelized cost of electricity. Renewable and Sustainable Energy Reviews 2011;15(9): 4470-4482.

[57] IER. Electrical Generating Costs 2012. [Internet]; 2012 [cited on 2016 Mar 11]. http://instituteforenergyresearch.org/analysis/electric-generating-costs-a-primer/

[58] U.S. EIA. Short term energy and summer fuels outlook (2016 values) [Internet]; 2016 [cited on 2016 Mar 11]. https://www.eia.gov/forecasts/steo/report/electricity.cfm

[59] Farrell, J. Minnesota’s Value of Solar: Can a Northern State’s New Solar Policy Defuse Distributed Generation Battles?. Institute for Local Self-Reliance Report 2014. Available at: http://www. ilsr. org/wp-content/uploads/2014/04/MN-Value-of-Solar-from-ILSR. pdf.

[60] Kantamneni, A., R.Winkler, L. Gauchia, and J. M. Pearce. Emerging economic viability of grid defection in a northern climate using solar hybrid systems. Energy Policy 95 (2016): 378-389.

[61] EPA. Cap and Trade. [Internet]; 2005 [cited on 2016 Feb 20]. Available at: https://www3.epa.gov/captrade/

[62] Buhre, B, Hinkley, J, Gupta, R, Wall, T, Nelson, P. Submicron ash formation from coal combustion. Fuel 2005;84(10):1206-1214.

[63] Sherwani, A, Usmani, J, Varun. Life cycle assessment of solar PV based electricity generation systems: A review. Renewable and Sustainable Energy Reviews 2010;14(1):540-544.

[64] Stoppato, A. Life cycle assessment of photovoltaic electricity generation. Energy 2008;33(2):224-232.

[65] Katzenstein W, Apt, J. Air emissions due to wind and solar power. Environmental Science and Technology 2009;43(2):253-258.

[66] Hernandez, R, Easter, S, Murphy-Mariscal, M, Maestre, F, Tavassoli, M, Allen, E, Barrows, C, Belnap, J, Ochoa-Hueso, R, Ravi, S, Allen, M. Environmental impacts of utilityscale solar energy. Renewable and Sustainable Energy Reviews 2014;29:766-779.

[67] Turney, D, Frthenakis, V. Environmental impacts from the installation and operation of large-scale solar power plants. Renewable and Sustainable Energy Reviews 2011;15(6):32613270.

[68] Wiginton LK, Nguyen HT, Pearce JM. Quantifying rooftop solar photovoltaic potential for regional renewable energy policy. Computers, Environment and Urban Systems. 2010;34(4):345-57.

[69] Nguyen HT, Pearce JM. Incorporating shading losses in solar photovoltaic potential assessment at the municipal scale. Solar Energy. 2012 May 31;86(5):1245-60.

[70] Kodysh JB, Omitaomu OA, Bhaduri BL, Neish BS. Methodology for estimating solar potential on multiple building rooftops for photovoltaic systems. Sustainable Cities and Society. 2013 Oct 31;8:31-41. 
[71] Dupraz C, Marrou H, Talbot G, Dufour L, Nogier A, Ferard Y. Combining solar photovoltaic panels and food crops for optimising land use: Towards new agrivoltaic schemes. Renewable Energy. 2011;36(10):2725-32.

[72] Dinesh H, Pearce JM. The potential of agrivoltaic systems. Renewable and Sustainable Energy Reviews. 2016;54:299-308.

[73] Tsoutsos, T, Frantzeskaki, N, Gekas, V. Environmental impacts from the solar energy technologies. Energy Policy 2005;33(3):289-296.

[74] United Nations. Sustainable Development Goals. [Internet]; 2016 [cited on 2016 Apr 20]. Available at: https://sustainabledevelopment.un.org/

[75] WHO. 7 Million Premature Deaths Annually Linked to Air Pollution. [Internet]; 2014 [cited on 2016 Feb 20]. Available at: http://www.who.int/mediacentre/news/releases/2014/airpollution/en/

[76] ASIRT. Annual Global Road Crash Statistics. [Internet]; 2016 [cited on 2016 Apr 20]. Available at: http://asirt.org/initiatives/informing-road-users/road-safety-facts/road-crash-statistics

[77] IFRC. World Disasters Report. [Internet]; 2014 [cited on 2016 Apr 20]. Available at: http://www.ifrc.org/world-disasters-report-2014/data

[78] IPCC. Special report on Renewable Energy Sources and Climate Change Mitigation. [Internet]; 2011 [cited on 2016 Apr 1]. Available at: http://www.uncclearn.org/sites/default/files/inventory/ipcc15.pdf .

[79] Harrington, L 2009 The Valuation of the Life Shortening Aspects of Work. EPA. Available at: https://yosemite.epa.gov/ee/epa/eerm.nsf/vwAN/EE-0297.pdf/\$file/EE-0297.pdf

[80] US DOT. 2015. Treatment of the Value of Preventing Fatalities and Injuries in Preparing Economic Analyses. [cited on 2016 Apr 1]. Available at: https://www.transportation.gov/sites/dot.gov/files/docs/VSL2015 0.pdf

[81] Partnoy, F. The Cost of a Human Life, Statistically Speaking. The Globalist. 2012, [Internet]; 2012 [cited on 2016 Apr 10]. http://www.theglobalist.com/the-cost-of-a-human-life-statistically-speaking

[82] Jamison DT, Breman JG, Measham AR, Alleyne G, Claeson M, Evans DB, Jha P, Mills A, Musgrove P, editors. Disease control priorities in developing countries. World Bank Publications; 2006.

[83] Nosrat, A.H., Swan, L.G. and Pearce, J.M., 2013. Improved performance of hybrid photovoltaic-trigeneration systems over photovoltaic-cogen systems including effects of battery storage. Energy, 49, pp.366-374.

[84] Mundada, A.S., Shah, K.K. and Pearce, J.M., 2016. Levelized cost of electricity for solar photovoltaic, battery and cogen hybrid systems.Renewable and Sustainable Energy Reviews, 57, pp.692-703.

[85] Basrawi, F., Yamada, T. and Obara, S.Y., 2014. Economic and environmental based operation strategies of a hybrid photovoltaic-microgas turbine trigeneration system. Applied Energy, 121, pp.174-183.

[86] Shah, K.K., Mundada, A.S. and Pearce, J.M., 2015. Performance of US hybrid distributed energy systems: Solar photovoltaic, battery and combined heat and power. Energy Conversion and Management, 105, pp.71-80.

[87] Murray C, Chambers R. Keeping score: fostering accountability for children's lives. The Lancet. 2015;386(9988):3-5.

[88] Yin, H, Powers, N. Do state renewable portfolio standards promote in-state renewable generation?. Energy Policy 2010; 38(2): 1140-1149. 
[89] Delmas, MA, Montes-Sancho, M. US state policies for renewable energy: Context and effectiveness. Energy Policy 2011; 39(5): 2273-2288.

[90] Fischer, C, Newell, R. Environmental and technology policies for climate mitigation. Journal of environmental economics and management 2008; 55(2): 142-162.

[91] Acemoglu, D, Aghion, P, Bursztyn, L, Hemous, D. The environment and directed technical change. The American Economic Review 2012; 102(1): 131.

[92] Convery, F., Ellerman, D, Perthuis, C. The European carbon market in action: Lessons from the first trading period. Journal for European Environmental \& Planning Law 2008; 5(2): 215-233.

[93] Bushnell, J, Chong, H, Mansur, E. Profiting from regulation: Evidence from the european carbon market. American Economic Journal: Economic Policy 2013; 5(4): 78-106.

[94] IER. Power Plant Closures. [Internet]; 2012 [cited on 2016 Apr 24]. Available at:

http://instituteforenergyresearch.org/topics/policy/power-plant-closures/

[95] Delina, L, Diesendorf, M. Is wartime mobilization a suitable policy model for rapid national climate mitigation? Energy Policy 2013;58:371-380.

[96] OECD. The Cost of Air Pollution. [Internet]; 2014 [cited on 2016 Apr 20]. Available at: http://www.keepeek.com/Digital-Asset-Management/oecd/environment/the-cost-of-air-pollution/summary/english 9789264210448-sum-en\#page1

[97] Romley, J A, Hackbarth, A, Goldman, DP. The Impact of Air Quality on Hospital Spending. RAND Corporation. [Internet] 2013 [cited on 2016 Apr 20]. Available at: http://www.rand.org/content/dam/rand/pubs/research briefs/2010/RAND RB9501.pdf

[98] Wilkinson, P, Smith, K, Joffe, A, Haines, A. A global perspective on energy: health effects and injustices. The Lancet 2007;370(9591):965-978.

\section{Figure Captions}

Figure 1. Coal fired electricity facilities located in the U.S. and the annual mortality due to coal emissions per 100,000 people in each U.S. state.

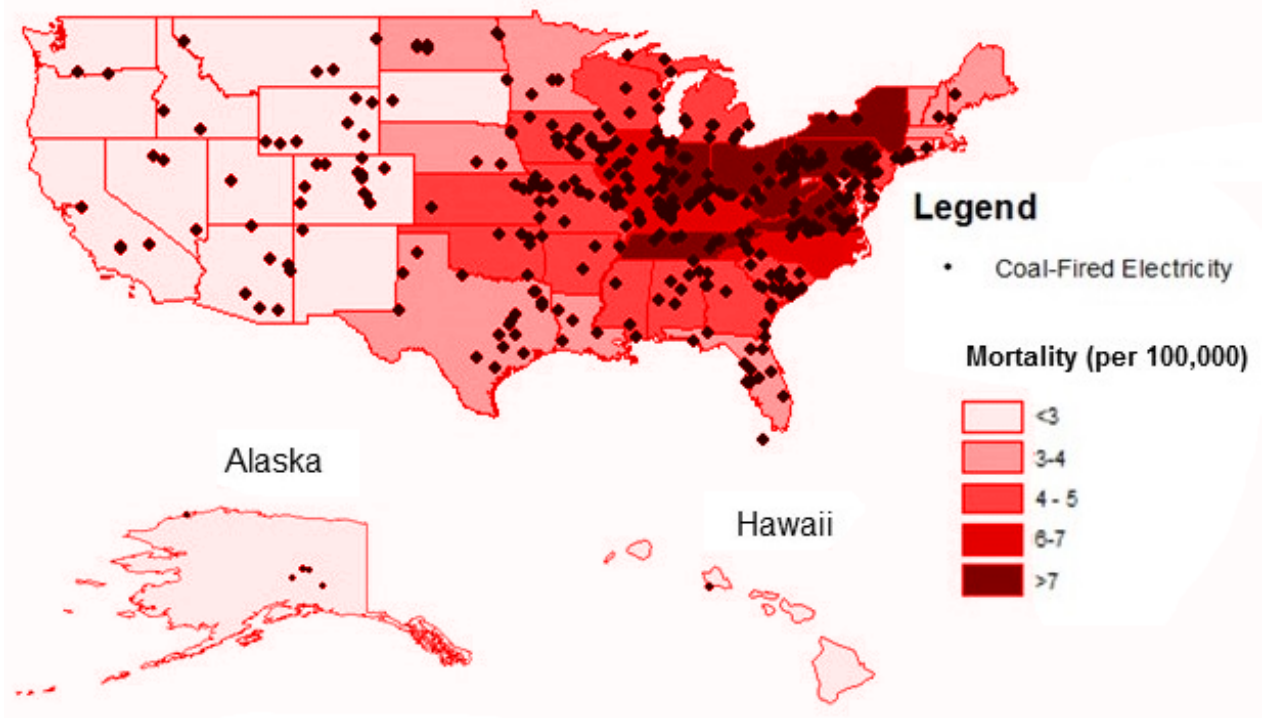

